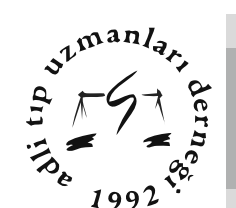

$1992^{\prime}$

\title{
Eozinofilik Arterite Bağlı Spontan Koroner Arter Diseksiyonu: Bir Olgu Sunumu
}

\author{
Eosinophilic Arteritis Related Spontaneous Coronary Artery Dissection: A Case Report
}

\author{
Gülden Çengel ${ }^{1}$, Esra Gürlek Olgun ${ }^{1}$, Alper Kures $^{2}$, Cafer Uysal ${ }^{1}$, Mehmet Ali Çakmak ${ }^{1}$, İsmail Özgür Can ${ }^{2}$
}

${ }^{1}$ Adli Tıp Kurumu İzmir Grup Bașkanlığı, Morg İhtisas Dairesi, Izmir

${ }^{2}$ Dokuz Eylül Üniversitesi Tip Fakültesi Adli Tip Anabilim Dalı, Izmir

\section{Özet}

Koroner arterin spontan diseksiyonu ani ölüm ve myokard enfarktüsünün nadir nedenlerinden biri olarak kabul edilmektedir. Spontan travmatik olmayan koroner arter diseksiyonu seyrek olarak meydana gelir. Koroner arterin eozinofilden zengin periarteriti (eozinofilik periarterit) koroner arter diseksiyonuna yol açabilmektedir. Koroner eozinofilik periarteritin intimal bozulmada ve diseksiyonda predispozan bir faktör olduğu ileri sürülmektedir. Literatürdeki eozinofilik periarteritli kadın olguların 1/3’ü gebe ya da peripartum dönemdedir. Olgumuzda, 35 yaşında, evinde fenalaşan, postpartum dönemdeki kadın olgu hastaneye ölü olarak getirilmiştir. Adli Tip Kurumu'nda yapılan otopsisinde alınan kalbe ait doku örneklerinin histopatolojik incelenmesinde koroner arterin sol ön inen dalında eozinofilik periarterite bağlı diseksiyon; tiroide ait doku örneklerinde ise tiroidit saptanmıştır. Literatürde otoimmun tiroidit ile birlikte eozinofilik periarterite bağ lı koroner arter diseksiyonu sonucu ölüm olgusu sayısı oldukça azdır. Genç postpartum dönemdeki kadınların ani ölümlerinde akla getirilmesi gereken bir patoloji olması nedeniyle önemli bulunmuştur.

Anahtar kelimeler: Postpartum, Arterit, Eozinofilik, Koroner, Diseksiyon.

\begin{abstract}
Spontaneous dissection of coronary arteries is accepted as one of the rare reasons of myocardial infarction. Spontaneous non-traumatic coronary artery dissection occurs rarely. Eosinophilic periarteritis of coronary artery may cause coronary artery dissection. Coronary eosinophilic periarteritis is put forward as predisposing factor of intimal impairment and dissection. In the literature; $1 / 3$ of women with eosinophilic periarteritis is pregnant or in postpartum stage. In our case, 35 aged postpartum woman, who was deteriorated at home is brought hospital as dead. In the histopathological examination of tissue samples taken by the autopsy, made in The Council of Forensic Medicine, dissection in the left descending branch of coronary artery related to eosinophilic periarteritis and thyroiditis in the thyroid tissue samples is observed. In the literature, there is a few death case, related eosinophilic periarteritis with. autoimmune thyroiditis. It is found important because of that it is one of the pathologies, which must come to mind firstly in postpartum period women deaths.
\end{abstract}

Keywords: Postpartum, Arteritis, Eosinophilic, Coronary, Dissection.

\section{Giriş}

Adli yönden araştırma konusu olabilecek ölümlerde, ölümün mekanizmasına, ölüm nedenine, ölümde rolü olabilecek etkenlere 1şık tutabilecek bulguları araştırmak amacıyla çeşitli incelemeler yapılmaktadır. Ülkemizde, medikolegal yönden değerlendirilmesi yapılan ölümlerin araştırıldığı çalışmalarda, otopsi serileri içinde, doğal orijinli ölümlerin olguların 1/7'si ile 1/3'ü arasında değiştiği gözlenmektedir. Ani ölüm olguları içerisinde doğal nedenli en sık ölüm nedeninin kardiyovasküler hastalıklar olduğu ve sıklıkla orta ve ileri yaşlarda görüldüğ̈̈i bilinmektedir.

Koroner kalp hastalıkları günümüzde mortalite ve morbiditenin en önemli nedenidir. Her zaman olmasa da sıklıkla aterosklerotik koroner arter hastalı̆̆ oluşmaktadır ve artmış kardiyak ölüm ve miyokard infarktüsü

Sorumlu Yazar: Alper Kureş

Dokuz Eylül Üniversitesi Tıp Fakültesi Adli Tip Anabilim Dalı, İzmir

E-mail: alperkures@hotmail.com

Geliş: 10.06.2014

Düzeltme: 27.06.2014

Kabul: 25.11.2014 ile ilişkilidir (6). Akut koroner sendrom ( AKS ), miyokard infarktüsü (Mİ) ve kararsız anginayı içeren akut miyokard iskemisi ile uyumlu semptomları tanımlamak üzere kullanılan bir terimdir (3). Spontan koroner arter diseksiyonu da Akut Koroner Sendromun nadir bir sebebidir. Olguların \%75-80'i kadındır ve bunların 1/3’ünü son 3 ayındaki gebeler ve doğum sonrası ilk 3 ay içindeki olgular oluşturmaktadır (9). Sol ön inen koroner arter (SÖİKA) en sık olarak ve \%80 oranında tutulmaktadır. Sol ana koroner arter diseksiyonu \%15 olguda bildirilmektedir. Az sayıda hastada tanı, akut koroner sendrom sirasinda ya bu sendrom nedeniyle yapılan koroner anjiyografi ile konabilir0 (1). Spontan koroner arter diseksiyonu ilk defa, 1931 yılında ani kardiak ölümden dolayı otopsisi yapılan 42 yaşında bir kadında tanımlanmıştır. O tarihten bu yana bildirilen pek çok olguda tanı otopside konulmuştur (4).

Koroner arter diseksiyonunun çoğu idiopatik oluşur. Bilinen sebepler azdır. Marfan sendromu, arteriosklerotik kardiovasküler hastalık, künt göğüs travması, egzersiz, kontraseptif kullanımı, sistemik lupus eritematozis ve kokain 
kullanımı ile ilişkili olduğu bildirilmiştir (4).

Eozinofilik arterit, Churg Strauss Sendromunun kalp tutulumuna dair bir bulgusu olabilen, spontan arter diseksiyonuna yol açabilen bir patolojidir. Robinowitz ve arkadaşları koroner eozinofilik arteritin intimal bozulma ve diseksiyonla sonuçlandığını öne sürmüşlerdir. (4) Ayrıca eozinofilik koroner arteritin Churg-Strauss Sendromu'nun kardiyak tutulum şekli olduğunu öne süren çalışmalarda vardır (1).

\section{Olgu Sunumu}

35 yaşında kadın olgu yenidoğan bebeğini emzirirken fenalaşıyor ve hastaneye ölü olarak getiriliyor. Adli Tıp Kurumu İzmir Grup Başkanlığ 1 Morg İhtisas Dairesinde yapılan otopsisinde üst dudakta sağda $0,3 \mathrm{~cm}$ ' lik sırık, alt dudakta sağda simetrik olarak aynı özellikte sıyrık, sağ dirsek iç yüzünde pikür izi ve pubis üst kısımda eski ameliyat nedbesi dışında lezyonun bulunmadığı görüldü.

İç muayenede beyin ve beyincik 1350 gr. tartılmış olup, sulkuslarda hafif silinme dışında bir özellik bulunmadı. Göğüs açıldığında her bir akciğer 500 gr. tartıldı ve ödemli olduğu saptand1. Kalp 300 gr. tartıldı. Kapak yapiları, aort ve ana damarsal yapılar ile myokard kesitlerinde makroskobik patolojik bulguya rastlanmadı. Koroner arter sol ön inen dalda, başlangıçtan itibaren $3 \mathrm{~cm}$ uzunlukta bir segmentin lümeninin kanamalı ve tromboze görünümde olduğu dikkati çekti. Tiroid bezinin normalden büyük, kesit yüzeyinin homojen olduğu görüldü. Batın organlarının incelenmesinde kayda değer makroskobik patolojik bulgu izlenmedi. Alınan iç organ örnekleri histopatolojik olarak incelendi. Beyin, beyincik, karaciğer, dalak, böbrekler ve sürrenallerde postmortem değişimler ve vasküler konjesyon; akciğerlerde akut alveoler şişme, yer yer intra-alveoler ödem ve kanama görüldü. Kalbin incelenmesinde koroner arterde intima ve media tabakalarının birbirinden ayrıldığ 1 (Şekil 1), media kas liflerinde dejenerasyon ile media ve adventisianın yoğun olarak eozinofil lökosit, plazma hücreleri, lenfositler ile infiltre olduğu dikkati çekti. Aynı özellikteki yangısal infiltrasyon subepikardial yağ dokusunda da görüldü (Şekil 2). Myokard kesitlerinde eski veya yeni enfarktuise ait bulgular görüilmedi. Histopatolojik olarak lenfositlerden zengin yangisal infiltrasyon izlendi. Bazı alanlarda germinal merkezler oluşturan lenfoid folliküller ve hafif derecede fibrozis bulunmaktaydı (Şekil 3). Uterus örneklerinde postpartum dönemle uyumlu özellikler, overlerde kistik folliküller ile korpus albikans dışında histopatolojik bulgu görülmedi. Adli Tip Kurumu İzmir Grup Başkanlığı Morg İhtisas Dairesinde kişiye ait kanın yapılan kimyasal analizinde alkol, uyutucu, uyuşturucu ve iç organ örneklerinde toksik maddelerden hiç biri saptanmadı.

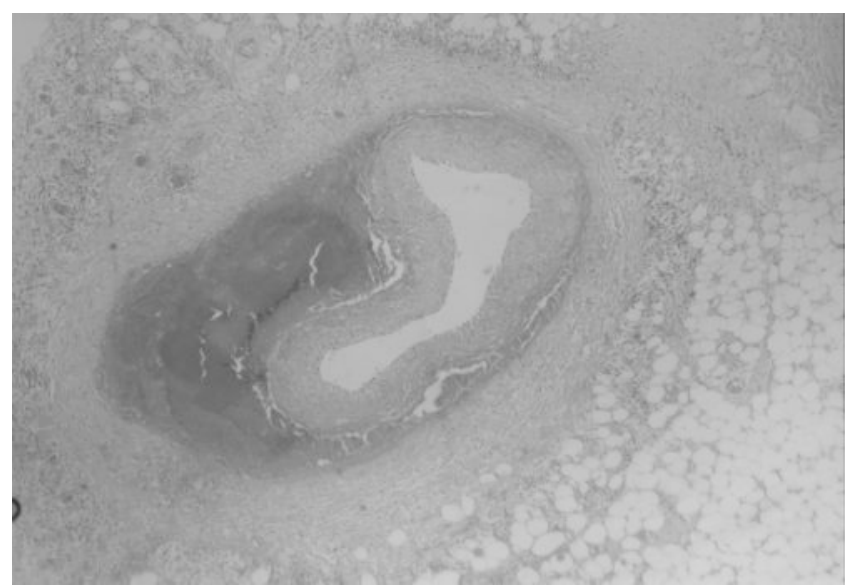

Şekil 1. Koroner arterde media ve adventisia tabakalarının birbirinden ayrıldığ 1 lökositlerden zengin yangısal infiltrasyon görülmektedir $(\mathrm{H} \& \mathrm{E}, \mathrm{x} 4)$.

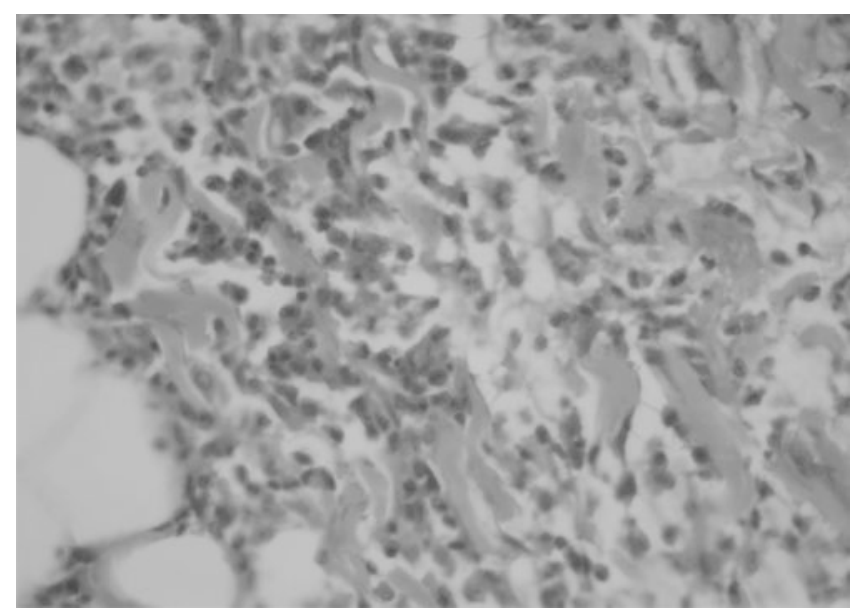

Şekil 2. Periarteriyel yă̆ dokuda eozinofil tabakalarının birbirinden ayrıldığ1 lökositlerden zengin yangısal infiltrasyon dikkati çekmektedir (H\&E, x10).

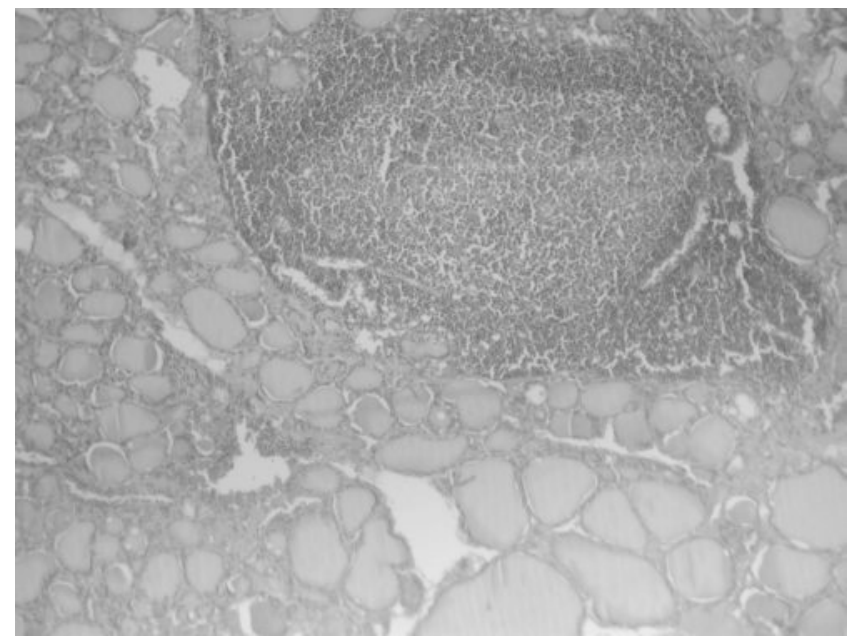

Şekil 3. Tiroid dokusunda germinal merkezler oluşturan lenfoid folliküller görülmektedir (H\&E, x4). 


\section{Tartışma ve Sonuç}

Otopsi ceset üzerinde yapılan tanısal amaçlı tıbbi bir uygulamadır. Amaç ölüm nedeninin saptanması veya hangi organların ölüme yol açan hastalıklardan ne biçimde ve ne kadar etkilendiklerinin saptanması olabilir. Ancak özünde hedeflenen hastanın niçin ve nasıl öldüğüne ilişkin sorulara karşlık bulmaktır. Gecikmiş veya atlanmış bir tanı, eksik veya yanlıș bir tedavi insanın ölümüne neden olabilir. Bunların otopside anlaşılmasının ölene doğrudan bir yarar sağlaması beklenemez. Otopsiden beklenen, ani beklenmedik ölümlerden alınacak dersler ile benzer durumdaki başka hastaların hayatlarının kurtarılabilmesidir. En gelişmiş ülkelerde bile; otopsi, olguların önemli bir kısmında hasta sağken bilinmesi çok yararlı olabilecek bilgiler sağlamaktadır. Sağlık sisteminin o kadar gelişmiş olmadığı ülkemizde yapılan otopsilerin büyük kısmında hastanın yaşarken tanısı konulamamış hastalıklar saptanmakta, klinik olarak farkına varılmamış ek lezyonlarla/insidental bulgularla karşlaşılmaktadır. Bu olgumuzda da postpartum bir olgunun, şüpheli ölümü sonrasında niçin öldüğü açıklığa kavuşturulmaya çalışılmıştır.

Koroner arterin spontan diseksiyon nedenlerinden biri olan eozinofilik periarteritin, daha önceden kardiovasküler problemi olmayan genç postpartum dönemdeki veya post menopozal dönemdeki kadınlarda daha sık olarak görülmekte olduğu; belirgin olarak sol ön inen koroner arter dalında meydana geldiği ve histolojik olarak perivasküler eozinofillerden zengin inflamasyon ile karakterize olduğu bildirilmektedir $(7,8)$.

Eozinofilik periarteritin başlıca 6 klinikopatolojik bulgusu vardır. a) Varyant anjina. (Daha çok akşamdan, erken sabah kadar görülür) b) Alerjik c) Ani ölüm. Genellikle sabahın erken saatlerinde görülür. d) Genellikle ana koroner arterlerde, özellikle sol inan koroner arterde görülen, adventisya ve periadventisyal yumuşak dokuları tutan bir eozinofilik infiltrasyondur (4). e) İnflamasyon bölgesinde fibrinoid nekroz ve granülomatoz alan görülmeyebilir f) diğer organlarda vaskülit görülmeyebilir. Spontan koroner diseksiyona yol açmayabilir (1). Eozinofilik koroner arterit tamamen izole olabilir. Churg Strauss sendromu hikayesi bulunmayan olgularda da görülebilir (2). İzole olan, spontan koroner arter diseksiyonu ile birliktelik göstermeyen olguların çoğu erkek iken, (5) spontan koroner arter diseksiyonu ile birlikte görülen olguların hemen hemen hepsi kadınlarda görülür (1). Eozinofilik arterit her ne kadar izole görülebilirse de genel olarak otoimmün tiroidit ile birlikte görülebilir (3). Bu olgumuzda da tiroide ait doku örneklerinde tiroidit saptanmıştır.

Olgumuza bakıldığında, nedeni çok çeşitli olan ani beklenmedik şüpheli ölümlerde, özellikle ölen kişi postpartum kadınsa, otopsinin ve histopatolojik incelemenin önemi daha iyi anlaşılmaktadır.

\section{Kaynaklar}

1. Kajihara H, Tachiyama Y, Hirose T, Takada A, Saito K, Murai T, Yasui W. et al. Eosinophilic coronary periarteritis (vasospastic angina and sudden death), a new type of coronary arteritis: report of seven autopsy cases and a review of the literature. Virchows Arch. 2013 Mar;462 (3):369. Takada, Aya

2. Lepper PM, Koenig W, Möller P, Perner S. A case of sudden cardiac death due to isolated eosinophilic coronary arteritis. Chest. 2005 Nov;128(5):3779.

3. Zagelidou H, Leodari R, Roupa Z, Maras D, Sapountzi-Krepia D, Terzis A. Death from spontaneous coronary artery dissection in a healthy postmenopausal woman. Am J Forensic Med Pathol. 2004 Jun;25(2):176-7.

4. Çolak N, Nazlı Y, Alpay F, Çakır Ö. Spontan koroner arter diseksiyonu: Dört olgu ve literatürün gözden geçirilmesi. Dicle Med J Cilt/Vol36, No 4, 294-300.

5. Yavuzgil O, Gürgün C, Hasdemir C, Kültürsay H. Sol ön inen koroner arterde spontan diseksiyon: Olgu sunumu. Arch Turk Soc Cardiol 2005;33(2):110-114.

6. Basso C, Morgagni GL, Thiene G. Spontaneus coronary artery idssection, a neglected cause of acute myocardila ischemia and sudden death. Heart 1996;75:451-454.

7. Fengping Y, Jue H, Qingchun Y, Fangxing H. A case of sudden death due to spontaneous coronary artery dissection. Am J Forensic Med Pathol 2011;32:312Y313).

8. Hanzlick R. Medical certification of death and cause of death statements. In: Handbook of Forensic Pathology. Ed: Froede RC. Northfield, College of American Pathologists, 2003.

9. Di Maio JV, Di Maio D. Forensic Pathology. 2 nd Ed., London: CRC Press, 2001. 